\title{
All about Vertical Farming: A Review
}

\author{
Gaganjot kaura, and Paras Chawlab \\ Electronics and Communication Engineering Department, Chandigarh University, \\ Gharuan,Punjab,India. \\ ${ }^{\mathbf{b}}$ Electronics and Communication Engineering Department, Chandigarh University, \\ Gharuan,Punjab,India.
}

Article History: Received: 11 January 2021; Accepted: 27 February 2021; Published online: 5 April 2021

\begin{abstract}
Agricultural land is becoming scarce and expensive day by day. With the rising world population, demand for food and land is continuously increasing which is necessitating to maximize food production per unit area. So the eyes are turning to Vertical framing approach which involves growing crops in stacked layers one above another in order to provide more crop yield per unit area of land. This article summarizes the complete concept of emerging area of agriculture with its various categories and techniques used throughout the world.
\end{abstract}

\section{Introduction}

With the world population quadrupling over the last century, the global population is expected to reach 9.8 billion by the year 2050( Www.Un.Org n.d.). Considering this, with increase in income within developing countries is pushing the global food demand. With the food demand expected to rise by $57 \%$ to $98 \%$ by 2050 ( hbr.org n.d.) and India's population is expected to rise up to 1.7 billion, hence making India world's most populated country which is going to increase food demands many folds [3], new agricultural practices which can complement the rural farm based agricultural food production are required to maintain food security. With reports ( www.cnbc.com n.d.) claiming that $68-70 \%$ of the total global population in 2050 will be living in urban centres, it is hence necessary to develop and integrate some efficient urban based food production system. Other factors to consider are reducing agricultural land area due to urban expansion and fixed yield rate as well as low nutrient quality of conventional farming. [6] estimated that in coming 50 years there will be rapid changes in climate that 10 of increment in temperature, $10 \%$ of cultivable land will be lost which will lead to imbalance in environment. He gave controlled environment as the answer for situation reversal. Technologies such as greenhouse assures safe and reliable food all the year round and we can locate them close to urban areas. Another way out to reduce agricultural footprint is stacking i.e. vertical farm concept which can be used regardless of location.

\subsection{What is Vertical Farm.}

Taking all these constraints into consideration, vertical spaces left un-utilised in urban buildings are being used to develop Vertical Farming. VF may be considered as a low-cost vertical greenhouse and micro-gardening system( Aerofarms.Com). With an eye towards relieving pressure off conventional agriculture system and increasing the crop yield, the VF systems are gaining mass attention worldwide. In VF, plants are stacked using shelves that can be suspended on a wall. This system maximises the space available. Majority of vertical farms are soil free i.e. soil is not needed for plant growth. Instead hydroponics[8] (bowl of water enriched with necessary nutrients) or aeroponics[8] (spraying of mist consisting water and nutrients to plant roots) is employed. Mostly artificial lights are used to stimulate plant growth but many a times it is used in union with natural sunlight. The artificial lights used maybe Light emitting diode (LED) Organic LED or High Pressure Sodium. The advantage of using LED is that it is highly efficient, highly durable and can emit light of specific wavelength[9] (A quality that we desire in VF). For effective production, these lights are made available for about 18 hours a day. Light shelves are used for effective and maximised light entry. As these systems rely on water based nutrient system (hydroponics)for production rather than soil, hence water requirements are also a factor to be considered. VF only requires $5 \%$ of the water required to grow the same quantity of vegetables[10] as grown in an open field. [10] compared the energy water and land requirements of hydroponic culture with conventional agriculture. Statistics and data were obtained from government statistics and crop budgets. It is compared with theoretical hydroponic data. It showed that hydroponic yield was $11+-1.7$ times higher but it also has $82+_{-} 11$ times requirement than conventional produce

With depleting groundwater levels and increasing water scarcity in the world, this $95 \%$ water being saved will prove to extremely crucial. VF not only solves the above mentioned water crisis, but can also be a solution for water logging as well as water pollution (due to fertilisers). The lack of water can be compensated by using two methods. First is recycling. Besides rainwater, grey water (water used once such as for washing hands, rooftop water etc.) can be used for VF once filtered. Second method is dehumidification. In this, the water that has evaporated is again gathered and used. With these lighting and water requirements comes an energy requirement. 
This energy being necessary to light up the LEDs, to pump the water, to maintain temperature (using ACs, Heat pumps etc.), to power technical appliances like ventilators, fans and to power nutrient mixing machinery. Solar panels or solar walls are mostly employed to meet these energy requirements whereas wind energy can also be utilised to develop necessary energy.

\section{Benefits of Vertical farm}

There is a version of Despommier important points mentioned by him in a book The Vertical Farm: Feeding the World in the 21st century. VF also holds some advantages over traditional farming[11] suggested five reasons for the need of vertical farming and [12]. Firstly, due to VF there can be a year round availability of nutrient rich vegetables. The effect of seasonality as in case of TF is absent in case of VF. Secondly, vegetables produced by TF (i.e. in open fields) may be subject to environmental factors and stresses like pests, floods, drought and climatic conditions. Further, the use of insecticides and pesticides may prove as a major threat to the health of the public. Whereas vegetables produced in VF employing hydroponics or aquaponics do not require any such pesticides or insecticides, neither do they require soil. Due to the vegetable being produced in controlled environment, they are technically risk free from all the factors mentioned above. Hence plant efficiency is higher, growing cycle is shorter in VF than in TF. Third, the yield per unit area of VF is much higher than TF. A vertical farm based acre has the ability to produce 4 to 6 acres of soil based farming, while for crops growing in tight clusters like strawberries, 30 soil-based farming acres is equivalent to 1 vertical farm acre. Fourth, the vegetables are easily available for the urban population as they do not require large distance transportation. This will greatly reduce fuel usage hence saving non-renewable resources (petrol, diesel etc.). VF, as discussed above also saves $95 \%$ of the water that would be required for TF for the same area and same crop. This will increase water availability. While VF offers many advantages over soil based farming, but it should be noted that it is not a viable process for all fruits and vegetables. Vegetables like potato cannot be effectively produced during VF. Hence traditional farming methods are still required for production. This paper suggests that in order to meet the ever rising global demand for food, TF methods being employed in rural areas will not suffice. Instead VF in urban areas and TF in rural areas must work in conjunction to meet the rising food demand.

\begin{tabular}{|c|c|}
\hline \multicolumn{2}{|c|}{ Environmental benefits of Vertical Farming } \\
\hline $\begin{array}{c}\text { Reduced } \\
\text { Water demand }\end{array}$ & $\begin{array}{l}\text { Only } 3 \% \text { water requirement compared to conventional farming, water demand reduces } \\
\text { due to use of hydroponics, aeroponics and recycling [10]. }\end{array}$ \\
\hline $\begin{array}{l}\text { High Yield } \\
\text { and Variety }\end{array}$ & $\begin{array}{l}\text { It produces high yield per unit area[13] and can produce variety of foods[14] at a } \\
\text { particular time because it can raise crops during any time of year discarding seasonality } \\
\text { issues and different crops can grow in different layers. }\end{array}$ \\
\hline Land usage & $\begin{array}{l}\text { As vertical farming is not restricted to one level [10] so growth per unit areas increases } \\
\text { due to more number of levels. Also it can go indoor, hence there is } 20 \text { times reduction in land } \\
\text { consumption as land is reducing day by day sue to urban sprawl[15]. }\end{array}$ \\
\hline $\begin{array}{r}\text { Recycling } \\
\text { organic waste }\end{array}$ & $\begin{array}{l}\text { In this technique water waste as well as nutrient solution can be reutilized using } \\
\text { hydroponics and aeroponics techniques. Fish waste is recycled using aquaponics. Organic } \\
\text { waste can be converted to compost (www.environmentalleader.com) as done by companies } \\
\text { like farmed here. }\end{array}$ \\
\hline $\begin{array}{l}\text { Climate } \\
\text { change and } \\
\text { disasters }\end{array}$ & $\begin{array}{l}\text { As grow indoor, climate changes have no effects on crops and also unaffected by natural } \\
\text { disasters such as wind ,droughts [11]. It also offers multiple harvests in a year. }\end{array}$ \\
\hline $\begin{array}{l}\text { Save fossil } \\
\text { fuel }\end{array}$ & $\begin{array}{l}\text { As tis farming is mostly done locally, hence reduces transportation cost and fuels burnt } \\
\text { in transportation and also reduces pollution.[17] }\end{array}$ \\
\hline $\begin{array}{l}\text { Explore } \\
\text { New Landscape }\end{array}$ & $\begin{array}{l}\text { As for vertical farming, old scraped locations are repaired and revived hence it helps in } \\
\text { ecosystem restoration. Many companies are using existing buildings( Aerofarms.Com) and } \\
\text { scrapped shipping containers ( cropbox.co ) }\end{array}$ \\
\hline \begin{tabular}{l}
\multicolumn{2}{c}{ Organic or } \\
Healthy food \\
provision/ no \\
pesticides
\end{tabular} & $\begin{array}{l}\text { As this farming is done without any fertilizer or pesticide, so it produces organic food } \\
\text { free of any chemicals or adulterations and hence reduces threat to various diseases [12]. }\end{array}$ \\
\hline
\end{tabular}

\section{Challenges to Vertical farms:}

\begin{tabular}{|c|c|}
\hline $\begin{array}{c}\text { Limited range of } \\
\text { crops }\end{array}$ & $\begin{array}{c}\text { As it is possible to grow only leafy vegetables and short crops using vertical } \\
\text { farming, so it is not possible to make100\% out of it. }\end{array}$ \\
\hline $\begin{array}{c}\text { High Energy } \\
\text { requirements }\end{array}$ & $\begin{array}{c}\text { Due to use of controlled environment which uses LED'S and various sensors[19], } \\
\text { it has high energy requirements. }\end{array}$ \\
\hline High startup costs & $\begin{array}{c}\text { If land is purchased in urban areas, then startup cost becomes high. Moreover, use } \\
\text { of solar panels and hydroponic/aeroponic apparatus increases initial costs. }\end{array}$ \\
\hline
\end{tabular}


Training required to produce skilled workforce
As this system is technology based, so skilled workforce or engineers are required. It can be done by less educated people like the conventional agriculture

\section{Techniques Used in Vertical Farms}

Farms are available in different shapes and sizes from simple two-level to multi stories tall. However, all vertical farms make use of one of three schemes that are soil less [20]for providing nutrition to crops - Hydroponics, Aeroponics, and even Aquaponics.

The following information describes these three growing systems:

\section{i. Hydroponics.}

This prevalent technique that is employed in Vertical farms, involves growing plants in nutrient solutions in soil less conditions [21]. A hydroponic system is one in which crops are grown using a nutrient rich water based solution. The root system is supported by some inert medium (peat moss, Rockwool etc.). [20]The nutrient supply is maintained and recirculated in order to sustain the nutrient level required by the plants with proper precaution taken to curb possible pathogens. Various categories of hydroponic systems are:

- $\quad$ Ebb and flow: In this type of systems, young plants are moved to trays where they sprout and form seedling. These trays are filled with mineral solution at regular intervals and then again water is pumped out or drained to reservoir. This happens at regular intervals.( https://www.freightfarms.com/hydroponics )

- Drip Irrigation: In this nutrient solution is prepared in main tank, plumbed to height and then released through drip emitters to end of plant. As water drips/flows down, wicking material takes the water to plant roots. Water left unconsumed by roots flows to bottom of panel and then re-fed back to main tank.).( https://www.freightfarms.com/hydroponics )

- Deep Water Culture: This technique is also known as lettuce raft method. In this technique plants are grown in rafts which floats in pool of nutrient solution. This method is mainly used to grow light weight and small crops such as herbs, basil, lettuce, spinach etc.( https://www.thespruce.com/hydroponic-gardens-the-lettuce-raft-method1939221

- Wick System: They are most basic type of hydroponics. They do not contain any moving parts. In this method, number of wicks are used to deliver water to roots from reservoir whereas in Deep water culture, roots are directly submerged in solution. Mainly used to grow herbs such as lettuce, rosemary etc. (https://www.thespruce.com/hydroponic-gardens-wick-system-1939222)

- Nutrient Film Technique: In this system, pump is used to transport nutrient solution to growing racks and drain pipe is used to take back unused nutrient solution. Growing rack is placed tilted at angle which allows water to drain towards drain pipe. New solution is constantly fed at higher end of pipe. Nutrient solution then flows in thin film over roots which ensures continuous watering but avoid complete soaking.( https://www.thespruce.com/hydroponic-gardens-nutrient-film-technique-1939220)

\section{ii. Aeroponics.}

In Aeroponics, a mist of nutrient rich solution is sprayed over the plant roots hence saving water. It is a part of hydroponics system in which the roots are stored continuously or exposed continuously in an area filled with fine droplets (fog or aerosol) of mineral solution. [22]This system has no substrate requirement and involves growth of plants in a growing chamber with roots suspended in deep air or a with occasional roots suspended in fine mist of nutrients. Providing good and maximum aeration is a key benefit of aeroponics.

An aeroponics system is definitely a system for farms, which uses up to $90 \%$ lesser water compared to the most hydroponics systems. Plants grown up in these type of systems have been proven to uptake minerals and vitamins, which makes the plants nutritionally beneficial as well as healthier [20]. Aero Farms, the aeroponics vertical farming firm in the US, is currently building the plantation at New Jersey.

\section{iii. Aquaponics.}

Thus technique is the amalgamation of aquaculture (growing, breeding and harvesting of fish) and hydroponics. It is a one step further of hydroponic system which involves mixing fish and plants in the ecosystem. [23], [24] Fishes are cultivated in indoor environments, which produce nutrient-rich waste and that is employed as a feeding source for those plants. The plants then filter the waste water that is recycled the fish ponds. Even though this technique is utilized in small scale vertical farm approaches, many commercial vertical farms just concentrate on producing just a couple of vegetable plants that grow fastly and do not incorporate a component of aquaponic. [25] This optimizes efficiency and modulates both the economics and production difficulties. But fresh standardized aquaponics systems might make help this closed-cycle system popular.

\section{Design setups of Vertical farming}

\section{Multi- level Horizontal systems}

It means number of horizontal layers are stacked one above another . It is mostly used for large-scale growing of one or many types of crops like lettuce or spinach. This system is made by stacking a traditional hydroponic[21], aquaponic[24] or aeroponic[22] horizontal layer one over the other to achieve a vertical structure...

The stacking of horizontal growing sytems can be achieved in Controlled Environment or in greenhouses. The decision of whether to use a greenhouse or SE also depends on the location, as greenhouses need to be located in areas where the irradiance of sunlight is more. Whereas controlled environment does not have any such 
requirement. They can be implemented anywhere with large enough space to support VF. Also CE is not much affected by the seasonality factors and can maintain a good amount of yield year-long thus increasing the food availability.

But maintaining similar conditions in all the stacked levels is a challenging tasks. Crop variation may occur due to different temperature, light in various levels which is highly undesirable. A study of a hydroponic system of 4 tier strawberry observed that the yield was higher at the highest level and lowest at the lower level with the reason being more availability of PAR photo synthetically active radiation [26]. Hence in order to guarantee that each level of the system takes equal and adequate resources (lighting, PAR etc.), a rotating mechanism is employed in greenhouse-based systems(www.skygreens,com). This mechanism continuously moves the levels in turn to avoid shading of lower levels hence ensuring growing conditions homogeneity at all levels.

\section{Reuse of Buildings}

It can be said to be a Multi-Floor tire system which is a slightly altered version of stacked horizontal system. Vacant Historical buildings in newer shrinking cities can be used for Vertical farms. Example is Aerofarms ( aerofarms.com ) which uses existing buildings for Vertical farming and 'The plant' in Chicago( plantchicago.org ). Parking areas or structures can also be used for such purpose. In this system, the levels are actually located at different floors of a building with separate conditions present in each floor. This is intended to produce a wide variety of crops.

\section{Shipping containers}

Unused shipping containers can be used for farming. Also they can be moved or relocated taking in view density of urban areas. Example. Freight farms[29], Growtainers( www.growtainers.co), Crop box(cropbox.co). These containers contain staked shelves, LED lights, drip irrigation and are digitally monitored.

\section{Rooftops}

Rooftops of buildings have enough space for Vertical farms. Rooftop Greenhouses have an advantage over SE that they utilize the light energy of the sun for plant growth whereas in SE, artificial lighting needs to be provided. Although greenhouse does require some extent of artificial lighting to make up for low sunlight days but still greenhouse is much more cost efficient than SE due to comparatively lesser requirement of artificial lighting. Stacked containers or steel containers also be used can be used for such purposes.eg. Brooklyn Grange ( www.brooklyngrangefarm.com .)

\section{Rotating systems}

Rotatory gardens include plants grown in multi levels of horizontal layers but they keep on changing their place i.e. horizontal plates are moving so that every plate can reach top layer where direct sunlight is available, these systems partially use sunlight and LEDs. Example is sky greens ( www.skygreens.com ). Also [33] grows systemonion using vertical farming technology in Philippines. Experiments were conducted in 3 different phases Aug2017, May 2017 and July 2017 using Hydroponic system with variance analysis of single factor. The study also compared suitability and growth difference per onion bulb with conventional soil system. It concluded that this technology Is acceptable to farmers for onion growth but the initial cost is high so requires subsidy from government.

\subsection{Vertical Systems \\ Green walls}

Green walls means growing plants in areas like the building facades. The plants can be drawn either vertically or in an inclined manner. Light availability is one of the major considerations while deciding the location of green walls. ( theurbandeveloper.com n.d.)Bukit Tomah Singapore is a 24 stories tall building in Singapore by City Development. It marks a reference in Guinness world records with its two façade based vertical gardens of around 2289 square meters. Central park Sydney also shows green walls. Latest studies (Song, Tan, \& Tan, 2018) indicated that façade areas when exposed to sunlight for half of the day were able to produce sufficient PAR with the PAR levels rising with height of building. It was also stated that building alignment also played a major role. [9] discussed light adequacy assessment for vertical farming which is a key unknown in plant growth. It presents report on sunlight adequacy for growth of leafy vegetables in relation to high density and high rise environment of Singapore. Seven green leafy vegetables were assessed and survey of PAR (photo synthetically active radiations) showed 2 to $35 \mathrm{~mol} 2 \mathrm{~d}-1$ daily integral value. These days Greens walls are also seen in Building entrances, gyms, swimming pools, ( greenturf.asia n.d. )shopping malls, reception areas etc.

All these findings are encouraging for green walls cultivation but they need to be further analysed to understand growing conditions in various regions of the world. The possible issues may include equal water arrangement from top to bottom, exposure to city pollution and difficulties in crop harvesting much above ground level.

\section{Cylindrical Growth Units}

CGU is employed to grow various herbs, lettuce and strawberries. In this system the plants are grown around a cylindrical unit (consisting of nutrient supply like a hydroponic substrate) in such a manner that they are above one another. A study (Touliatos, Dodd, \& McAinsh, 2016) concluded that cylindrical growth unit yield per unit floor area was larger than that of a horizontal surface. Supplementary artificial lightings can further improve crop yield and uniformity. [13] In this comparison is made between vertical farming system and horizontal farming system using lettuce crop with hydroponics. Plants were grown in controlled environment in perlite, with halide lamps for 
artificial light. Light distribution (photon flux density) and shoot fresh weight were assessed. Both decreased significantly but VF (vertical farming system) produced more crops per unit area compared to horizontal. So it clearly indicates an attractive solution to horizontal hydroponics.

\section{Cylindrical Rotatory systems}

Rotatory systems are also employed with cylindrical units, in which plants rotates around a centre unit mostly light source LEDs and they reach a certain level at particular time so that all plants can get equal light. Volksgarden (omegagarden.com ) uses this technique with vertical farming and contain 120 rotatory modules with Footprint 960 sq ft. 120' x 8'. [37] showed growing of lettuce (Rex, Nanda and Canasta) rotatory system and also cabbage in a cylindrical multitier system with hydroponics using RB( Red and BLUE) Led lightening. PAR (Photo synthetically Active Radiations) at $63 \mu \mathrm{mol} / \mathrm{m} 2$ level produced better development in Canasta but low fresh weight in 'Rex' and 'Nanda'. Cultivation of cabbage in vertical stack system within cylindrical unit produced $47 \%$ more plant density in comparison to rotation system.
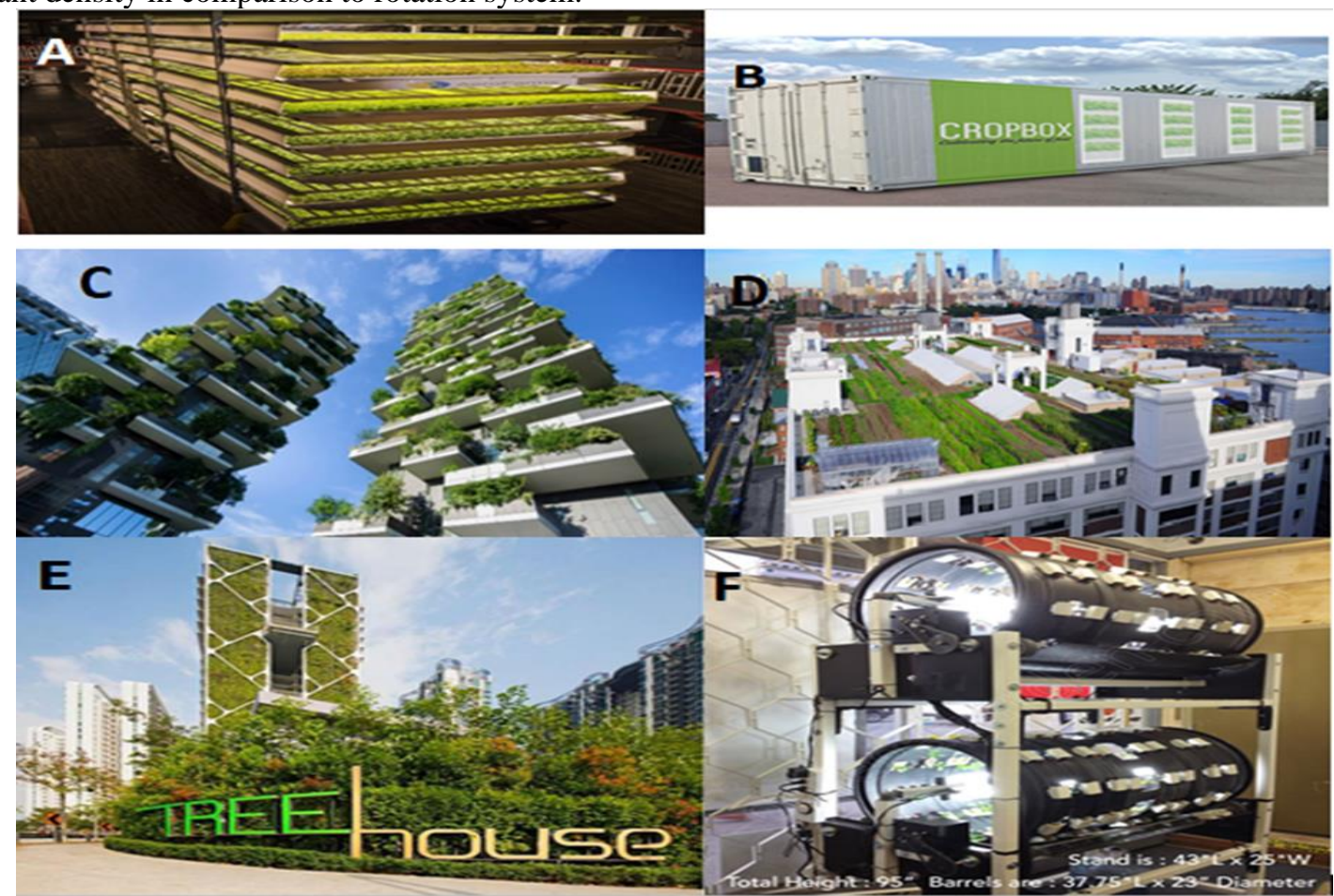

Fig. 1.(A) MULTI LEVEL (https://aerofarms.com/farms/ )(aerofarm uses existing buildings)

(B) BALCONIES (https://foodtank.com/news/2019/12/16-initiatives-changing-urban-agriculture-throughtech-and-innovation/)

(C) GREENWALLS (https://www.straitstimes.com/singapore/environment/the-worlds-largest-verticalgarden-its-right-here-in-singapore

(D) ROOFTOPS ( https://www.brooklyngrangefarm.com/about-brooklyn-grange-1)

(E) CYLINDRICAL GROWTH UNITS( https://omegagarden.com/ )

(F) SHIPPING CONTAINERS (https://cropbox.co/index.php/upgrades)

Existing Vertical Farms

\begin{tabular}{|l|l|l|l|}
\hline S.no & \multicolumn{2}{|c|}{$\begin{array}{l}\text { Compatible } \\
\text { chttps://www.verticalfarming.com/food- } \\
\text { crops/) }\end{array}$} & $\begin{array}{l}\text { Profitable Crop } \\
\text { grown(https://www.agrifarming.in/profitable- } \\
\text { crops-for-vertical-farming-a-full-guide) }\end{array}$ \\
\hline 1 & Summer squash & Herbs & Chard \& collard greens \\
\hline 2 & Peppers & Lettuce & Basil (Sweet, Lemon, Cinnamon) \\
\hline 3 & $\begin{array}{l}\text { Microgreens \& } \\
\text { sprouts }\end{array}$ & Spinach & Lettuce (Romaine, Butterhead, Red Leaf, etc.) \\
\hline 4 & $\begin{array}{l}\text { Mushrooms } \\
5\end{array}$ & Tomatoes & Chives \& mint \\
\hline
\end{tabular}




\begin{tabular}{|c|c|c|c|c|c|c|c|}
\hline $\begin{array}{c}\text { S.N } \\
\mathrm{O}\end{array}$ & $\begin{array}{l}\text { COMPAN } \\
\mathrm{Y}\end{array}$ & $\begin{array}{c}\text { WEBSIT } \\
\text { E }\end{array}$ & AREA & $\begin{array}{c}\text { TECHNOLOGY/STR } \\
\text { UCTURE/SET UP }\end{array}$ & $\begin{array}{c}\text { TYPE } \\
\text { OF } \\
\text { CROP } \\
\text { S }\end{array}$ & $\begin{array}{c}\text { LIGH } \\
\text { T } \\
\text { SOUR } \\
\text { CE } \\
\end{array}$ & REMARKS \\
\hline 1 & $\begin{array}{c}\text { SKY } \\
\text { GREENS } \\
\text { (SINGAP } \\
\text { ORE) }\end{array}$ & $\begin{array}{c}\text { https://w } \\
\text { ww.skygr } \\
\text { eens.com/ } \\
{[32]}\end{array}$ & $\begin{array}{c}\text { 9Mtr* } \\
6.5 \\
\text { Mtr } \\
\text { (per } \\
\text { Rack) }\end{array}$ & $\begin{array}{l}\text { 1.uses Rotating layers } \\
\text { of growing troughs } \\
\text { mounted on a A-shape } \\
\text { aluminium frame } \\
\text { 2.Rotation is powered } \\
\text { by hydraulic water- } \\
\text { driven system utilising } \\
\text { the momentum of } \\
\text { flowing water }\end{array}$ & $\begin{array}{c}\text { Sky } \\
\text { Lettuce } \\
\text {,Shang } \\
\text { hai } \\
\text { Green, } \\
\text { Sky } \\
\text { Chines } \\
\text { e } \\
\text { Cabbag } \\
\text { e, Sky } \\
\text { Cai } \\
\text { Xin, } \\
\text { Sky } \\
\text { Spinac } \\
\text { h }\end{array}$ & $\begin{array}{c}\text { Natura } \\
1 \\
\text { Sunlig } \\
\text { ht }\end{array}$ & $\begin{array}{cc}-\quad \text { world's } \\
\text { first low } \\
\text { carbon } \\
\text { vertical } \\
\text { farm } \\
\text { - hydraulic } \\
\text { driven }\end{array}$ \\
\hline 2 & $\begin{array}{c}\text { CROPBO } \\
\text { X } \\
\text { (NORTH } \\
\text { CAROLI } \\
\text { NA, USA) }\end{array}$ & $\begin{array}{l}\text { https://cro } \\
\text { pbox.co/i } \\
\text { ndex.php } \\
{[18]}\end{array}$ & $\begin{array}{c}\text { 320sq. } \\
\text { ft (per } \\
\text { Contai } \\
\text { ner) }\end{array}$ & $\begin{array}{l}\text { 1.Crop box is all about } \\
\text { growing the equivalent } \\
\text { of an acre of field } \\
\text { grown crops or } 2,200 \\
\text { square feet of } \\
\text { greenhouse space } \\
\text { within a } 320 \text { sq. ft. } \\
\text { footprint in Container }\end{array}$ & $\begin{array}{l}\text { Herbs, } \\
\text { Greens } \\
\& \\
\text { Lettuce } \\
\quad, \\
\text { Strawb } \\
\text { erries, } \\
\text { Fodder } \\
\text { s, } \\
\text { Microg } \\
\text { reens } \\
\end{array}$ & LED & $\begin{array}{c}\text { - Can grow } 1 \\
\text { acre of } \\
\text { crops in a } \\
\text { single } \\
\text { shipping } \\
\text { container } \\
\text { - uses } 90 \% \\
\text { less water }\end{array}$ \\
\hline 3 & $\begin{array}{c}\text { AEROFA } \\
\text { RMS } \\
\text { (NEWAR } \\
\text { K, NJ, } \\
\text { USA) }\end{array}$ & $\begin{array}{c}\text { https://aer } \\
\text { ofarms.co } \\
\text { m/farms/ } \\
\text { [27] }\end{array}$ & $\begin{array}{c}3 \text { no. } \\
\text { farms } \\
: \\
30,000 \\
\text { sq.ft., } \\
70,000 \\
\text { sq.ft., } \\
5500 \\
\text { sq.ft. }\end{array}$ & $\begin{array}{c}\text { 1. uses smart } \\
\text { aeroponics to mist the } \\
\text { roots of greens with } \\
\text { nutrients, water, and } \\
\text { oxygen. } \\
\text { 2. closed loop system, } \\
\text { using } 95 \% \text { less water } \\
\text { than field farming and } \\
40 \% \text { less than } \\
\text { hydroponics. }\end{array}$ & $\begin{array}{c}\text { Microg } \\
\text { reens, } \\
\text { lettuce }\end{array}$ & LED & \\
\hline 4 & $\begin{array}{c}\text { NUVEGE } \\
\text { (KYOTO, } \\
\text { JAPAN) }\end{array}$ & $\begin{array}{c}\text { https://agr } \\
\text { itecture.tu } \\
\text { mblr.com } \\
\text { /post/274 } \\
40882258 \\
\text { /nuvege } \\
\text { [38] }\end{array}$ & $\begin{array}{l}30,000 \\
\text { sq ft } \\
\text { horizo } \\
\text { ntal } \\
\text {,57000 } \\
\text { sq. ft } \\
\text { vertica } \\
1\end{array}$ & $\begin{array}{l}\text { 1. Nuvege's innovative } \\
\text { hydroponic technology } \\
\text { is unlike any other } \\
\text { conventional } \\
\text { hydroponic system that } \\
\text { exists today. } \\
\text { 2. Nuvege's proprietary } \\
\text { lighting network } \\
\text { (NLN) increases the } \\
\text { yield rate of vegetable } \\
\text { growth by equalizing } \\
\text { light emissions that } \\
\text { also advance } \\
\text { photosynthesis through } \\
\text { increased carbon } \\
\text { dioxide levels. }\end{array}$ & Lettuce & LED & $\begin{array}{c}\text { - } \quad \text { has LED } \\
\text { lighting } \\
\text { tuned to } \\
\text { two types } \\
\text { of } \\
\text { chlorophyl } \\
\text { 1, blue and } \\
\text { red } \\
\text { - produces } 6 \\
\text { million } \\
\text { lettuces a } \\
\text { year } \\
\text { customers } \\
\text { from } \\
\text { Subway } \\
\text { and } \\
\text { Disneylan } \\
\text { d Tokyo. }\end{array}$ \\
\hline
\end{tabular}




\begin{tabular}{|c|c|c|c|c|c|c|c|}
\hline 5 & $\begin{array}{c}\text { PLANT } \\
\text { CHICAG } \\
\text { O } \\
\text { (CHICAG } \\
\text { O,USA) }\end{array}$ & $\begin{array}{l}\text { https://pla } \\
\text { ntchicago } \\
\text {.org/ } \\
\text { [28] }\end{array}$ & $\begin{array}{l}100,00 \\
0 \text { sq.ft }\end{array}$ & $\begin{array}{l}\text { 1. E5 uses combination } \\
\text { of Aquaculture and } \\
\text { hydroponics, which } \\
\text { allows to raise fish and } \\
\text { grow produce without } \\
\text { soil. The fish "waste" } \\
\text { fertilizes the plants. } \\
2 . \text { They have } \\
\text { successfully } \\
\text { experimented with } \\
\text { homemade fish food } \\
\text { recipes and using } \\
\text { biomaterials to } \\
\text { increase nutrition while } \\
\text { lowering costs. }\end{array}$ & $\begin{array}{l}\text { Herbs, } \\
\text { Micro } \\
\text { greens }\end{array}$ & $\begin{array}{l}\text { Natura } \\
1 \\
\text { Sunlig } \\
\text { ht }\end{array}$ & $\begin{array}{l}\text { 1. It is also involved } \\
\text { in Public workshops, } \\
\text { equip people and } \\
\text { businesses with the } \\
\text { tools to live more } \\
\text { sustainably through } \\
\text { community-driven, } \\
\text { hands-on programs } \\
\text { and innovative } \\
\text { research projects. }\end{array}$ \\
\hline 6 & $\begin{array}{l}\text { FREIGHT } \\
\text { FARMS } \\
\text { (BOSTO } \\
\text { N,USA) }\end{array}$ & $\begin{array}{c}\text { https://w } \\
\text { ww.freig } \\
\text { htfarms.c } \\
\text { om/home } \\
\text { [29] }\end{array}$ & $\begin{array}{c}320 \text { sq. } \\
\text { ft (Per } \\
\text { shippi } \\
\text { ng } \\
\text { contai } \\
\text { ner ) }\end{array}$ & $\begin{array}{l}\text { 1. Smartest hydroponic } \\
\text { farm inside hipping } \\
\text { container. } \\
\text { 2.Greenery's plants } \\
\text { grow vertically indoors } \\
\text { without soil, getting } \\
\text { nutrition from water } \\
\text { and light energy from } \\
\text { powerful LEDs+E4 }\end{array}$ & $\begin{array}{l}\text { Greens, } \\
\text { lettuces }\end{array}$ & LED & $\begin{array}{l}\text { 1. Series of sensors } \\
\text { \& pumps maintain } \\
\text { perfect water } \\
\text { conditions for plants } \\
\text { germinating in the } \\
\text { table's dual-irrigated } \\
\text { troughs. } \\
2 \text { Cyclical system } \\
\text { senses and equalizes } \\
\text { nutrient levels, and } \\
\text { waters seedlings on a } \\
\text { regular schedule. }\end{array}$ \\
\hline 7 & $\begin{array}{l}\text { VERTI } \\
\text { CROP } \\
\text { (VANCO } \\
\text { UVER,C } \\
\text { ANADA) }\end{array}$ & $\begin{array}{c}\text { http://gro } \\
\text { w.verticr } \\
\text { op.com/v } \\
\text { ertical- } \\
\text { farming/ } \\
\text { [39] }\end{array}$ & $\begin{array}{c}50 \\
\mathrm{ft} * 70 \mathrm{ft} \\
\text { (per } \\
\text { rack) }\end{array}$ & $\begin{array}{l}\text { 1. involves high } \\
\text { density verical } \\
\text { cropping, fully } \\
\text { automated, closed loop } \\
\text { conveyer hydroponic } \\
\text { vertical farming } \\
\text { system. } \\
\text { 2. There are } 120 \text { racks } \\
\text { with } 24 \text { growing trays } \\
\text { on each rack which } \\
\text { produces as much food } \\
\text { as a } 16 \text {-acre farm. }\end{array}$ & $\begin{array}{l}\text { Leafy } \\
\text { greens, } \\
\text { microg } \\
\text { reens } \\
\text { and } \\
\text { strawb } \\
\text { erries }\end{array}$ & $\begin{array}{c}\text { Natura } \\
1 \\
\text { Sunlig } \\
\text { ht }\end{array}$ & $\begin{array}{l}\text { They claim } 20 \text { times } \\
\text { more yield \& uses } \\
\text { only } 8 \% \text { of the water } \\
\text { typically required for } \\
\text { soil farming }\end{array}$ \\
\hline 8 & $\begin{array}{c}\text { GROWT } \\
\text { AINERS } \\
\text { (TEXAX, } \\
\text { USA) }\end{array}$ & $\begin{array}{c}\text { http://ww } \\
\text { w.growtai } \\
\text { ners.com/ } \\
\text { [30] }\end{array}$ & $\begin{array}{l}\text { Shippi } \\
\text { ng } \\
\text { contai } \\
\text { ners } \\
\left(20^{\prime},\right. \\
40^{\prime}, \\
45^{\prime} \\
\text { and } \\
53^{\prime} \\
\text { sizes })\end{array}$ & $\begin{array}{l}\text { 1. use } 20^{\prime}, 40^{\prime}, 45^{\prime} \\
\text { and } 53^{\prime} \text { insulated } \\
\text { shipping containers } \\
2 \text { deals in horticultural, } \\
\text { floriculture \& } \\
\text { agricultural products in } \\
\text { all environments and } \\
\text { climates. } \\
\text { 3.Each chamber is } \\
\text { outfitted with a } \\
\text { proprietary, self- } \\
\text { contained adjustable } \\
\text { aluminum rack system, } \\
\text { which can contain any } \\
\text { number of vertical } \\
\text { production and } \\
\text { propagation levels. }\end{array}$ & $\begin{array}{l}\text { Microg } \\
\text { reens, } \mathrm{L} \\
\text { ettuces } \\
\text { and } \\
\text { leafy } \\
\text { greens, } \\
\text { Flower } \\
\text { s }\end{array}$ & LED & $\begin{array}{l}\text { Each level of the 6'- } \\
\text { 8' tall rack system } \\
\text { can contain an } \\
\text { appropriate number } \\
\text { of crop-specific LED } \\
\text { fixtures and a fully } \\
\text { equipped irrigation } \\
\text { system }\end{array}$ \\
\hline
\end{tabular}




\begin{tabular}{|c|c|c|c|c|c|c|c|}
\hline 9 & $\begin{array}{c}\text { BROOKL } \\
\text { YNGRAN } \\
\text { GE } \\
\text { (BROOK } \\
\text { LYN } \\
\text {,NY,USA) }\end{array}$ & $\begin{array}{c}\text { https://w } \\
\text { ww.brook } \\
\text { lyngrange } \\
\text { farm.com } \\
/ \\
{[31]}\end{array}$ & $\begin{array}{c}5.6 \\
\text { acres } \\
\text { with } \\
135,00 \\
0 \\
\text { square } \\
\text { feet }\end{array}$ & $\begin{array}{l}\text { 1. leading rooftop } \\
\text { farming ,hydroponics } \\
\text { programs and intensive } \\
\text { green roofing business } \\
\text { in the US. } \\
\text { 2.Includes operating } \\
\text { the world's largest } \\
\text { rooftop soil farms, } \\
\text { located on three roofs } \\
\text { in New York City, and } \\
\text { grow over 80,000 lbs of } \\
\text { organically-cultivated } \\
\text { produce per year. }\end{array}$ & $\begin{array}{l}\text { All } \\
\text { varities } \\
\text { of } \\
\text { agricult } \\
\text { ure } \\
\text { product } \\
\text { s,Natur } \\
\text { ally- } \\
\text { manag } \\
\text { ed } \\
\text { honey } \\
\text { bee } \\
\text { hives }\end{array}$ & $\begin{array}{c}\text { Natura } \\
1 \\
\text { Sunlig } \\
\text { ht }\end{array}$ & \\
\hline 10 & $\begin{array}{c}\text { GREEN } \\
\text { GIRL } \\
\text { (Memphis } \\
\text {, } \\
\text { Tennessee } \\
\text { USA) }\end{array}$ & $\begin{array}{c}\text { https://w } \\
\text { ww.green } \\
\text { girlprodu } \\
\text { ce.com/ } \\
{[40]}\end{array}$ & $\begin{array}{c}2.5 \mathrm{~m} \\
* 1.5 \mathrm{~m} \\
\text { (per } \\
\text { Rack) }\end{array}$ & $\begin{array}{l}\text { 1.Only microgreens } \\
\text { producer and } \\
\text { hydroponic } \\
\text { Educators/Trainers } \\
\text { withing the memphis } \\
\text { food community. } \\
\text { 2. uses LED } \\
\text { Technology and } \\
\text { Hydroponic process of } \\
\text { 'Nutrient Film } \\
\text { technique (NFT) }\end{array}$ & $\begin{array}{l}\text { Microg } \\
\text { reens, } \mathrm{L} \\
\text { ettuces }\end{array}$ & LED & $\begin{array}{c}\text { 1. Organises training } \\
\text { programmes/worksh } \\
\text { ops }\end{array}$ \\
\hline 11 & $\begin{array}{l}\text { OMEGA } \\
\text { GARDEN } \\
\text { (BRITISH } \\
\text { COLUMB } \\
\text { IA,CANA } \\
\text { DA) }\end{array}$ & $\begin{array}{l}\text { https://om } \\
\text { egagarde } \\
\text { n.com/ } \\
{[36]}\end{array}$ & $\begin{array}{l}37.75 " \\
\text { length } \\
* 23^{\prime \prime} \\
\text { Diame } \\
\text { ter } \\
\text { (per } \\
\text { Barrel } \\
\text { ) }\end{array}$ & $\begin{array}{l}\text { 1.uses rotary } \\
\text { Hydroponics system in } \\
\text { Barrel (cylinders) } \\
\text { 2.With a footprint of } \\
\text { just } 960 \text { sq. ft., the } \\
\text { internal surface } \\
\text { growing area is } 2280 \mathrm{sq} \\
\mathrm{ft} \text {, equivalent to } \$ 263 \\
\text { per sq } \mathrm{ft} \text { of surface } \\
\text { growing area. }\end{array}$ & $\begin{array}{l}\text { Basil,le } \\
\text { ttuce,st } \\
\text { rawber } \\
\text { ries,to } \\
\text { matoes, } \\
\text { marigo } \\
\text { ld } \\
\text { flowers }\end{array}$ & LED & $\begin{array}{l}\text { 1.Low power } \\
\text { requirements as } \\
\text { operate on } 12 \text { volt } \\
\text { D.C. or } 110 / 120 \text { volt } \\
\text { A.C. } 2 . \text { Fully } \\
\text { insulated, with } \\
\text { HVAC and all } \\
\text { control systems }\end{array}$ \\
\hline
\end{tabular}




\section{Plants grown in Vertical Farming}

The variety of crops that can be grown in VF is currently limited. Leafy vegetables [41] are mostly preferred in this. This is because of a number of reasons. First, they are small in size. This means it requires less area to grow which is an important parameter in indoor VF. Second, due to them being small in size, they grow in large numbers hence increasing the yield and income per unit area. Third, their growth time is low, hence the amount of crops grown over a year further increases. The main crop types in percentages of them being produced are:

$$
\begin{array}{ll}
\text { - } & \text { Leafy Greens(57\%) } \\
\text { - } & \text { Flowers(10\%) } \\
\text { - } & \text { Microso greens(6\%) } \\
\text { - } & \text { Tomatoes(16\%) }
\end{array}
$$

Leafy crops (salad greens and herbs) are expected to have consistent demand over the future years. Producers producing micro green crops need to continuously innovate and improve their technology if they want to maintain profits. Apart from these, VF is also employed by medicinal industries as well. The common medical plants ( www.verticalfarming.com//pharmaceutical-crops/)are aloe Vera, angelica, wild yam, rosemary, clove, blood root, ginger, black cohosh etc. More studies need to be conducted to grow other varieties of crops in VF so as to increase crop diversity and raise profits, with some growers implementing VF to grow strawberries[15] as of late. Further research needs to be done so as to implement plant grown in horticulture systems in VF. Crop choice is determined by the space present between levels ( www.growtainers.com )as shorter crops like herbs and spinach allow a higher number of levels and hence higher yield and profit. Taller crops(pepper, tomatoes etc.) may require a change in cultivation methods to achieve the same yield.

\section{Effect of LED on Crop efficiency}

LED lighting can manipulate how plants are growing to some extent[43]. In doing so, it was observed that things like leaf size and shape, leaf texture and density can be manipulated. Also, nutrient content regulation is a known effect.

LEDs are preferred because it provides with ability to select specific desired wavelengths which is highly desirable for specific plant growth. Red light of range $600-700 \mathrm{~nm}$ is known to stimulate stem elongation, leaf expansion and is most efficient to promote single leaf photosynthesis. Further studies have stated that blue light of range 400-500 $\mathrm{nm}$ is about $30 \%$ less efficient in promoting single leaf photosynthesis than red light. Red and blue LEDs' [44]are preferred as they have shown better results than other colours. Red light being mandatory for photosynthesis while the blue being necessary for optimal environment creation. [44] presented effects of artificial light for indoor VF (vertical farming) on plant Typhonium Flagelliforme. It studied CFL, blue and red color LEDs with wavelength of 475 and $650 \mathrm{~nm}$ w.r.t height, chlorophyll content and $\mathrm{CO} 2$ release and water content in leaves of plant. Results showed that blue light effects height of plant in positive way as well as water content in leaves and red light promotes chlorophyll production in leaves but emits more $\mathrm{CO}$.

Increase in the amount of blue light may increase leaf thickness and chloroplast development regulation while decreasing stem elongation and leaf length. Light absorption in chlorophyll takes place most effectively in 400-700 $\mathrm{nm}$ regions [45] of PAR spectrum (red and blue regions). Green (500 to $600 \mathrm{~nm}$ ) is often undesirable as it was observed that their absorption by chloroplast was minimal. But further studies stated that red and blue only penetrated the upper few layers of the leaves whereas green has the ability to penetrate deeper, hence green increases the $\mathrm{CO} 2$ fixation in the lower layers leading to overall increase in the whole crop photosynthesis. Hence a mixture of red and blue light with a little green light is ideal. Further, using specific bands of LEDs holds potential in plant disease and pest pressure reduction.

[46] presented a study of optimizing plant growth with the use of LED light and analyzed the best method to reduce power consumption. They used micro controller produce variable intensity and conducted two experimented 1 . Using RBW (Red/Blue/White) LEDs in ratio 16:4:2 for 12 hours. 2. Using RBFR (Re/ Blue/Far Red) in ratio 16:4:16 for 12 hours photoperiod. Results showed that this variable intensity method is good in reducing power consumption, increasing mortality and flowering process reduced significantly with RF treatment.

\section{Economics of Vertical Farm}

Since VF requires the usage of a controlled environment glass house, therefore energy usage could possibly be likely to be more in comparison to traditional grown plants. The use of artificial lights KED's and HPs(High Pressure Sodium ) lamps often [47]used in greenhouses raise the energy costs. It's been discovered that glasshouse production of kale utilizes $0.08 \mathrm{GWh} /$ ton in comparison to merely $0.0014 \mathrm{GWh} /$ ton to get field-grown salads[10]. When compared with outcomes of traditional field production, the glasshouse needed water demand that are 10 times greater in comparison with traditional production.

Node Farm [48] a small company of southern Stockholm calculated the energy consumed per functional unit and estimated it to be around 3.4GJ per square meter of area used.

Solutions suggested to reduce this is either combined greenhouse with Vertical farm which uses sunlight as well as LED's or the process of district heating can also help, which is already employed in Sweden. This process is used to heat offices or houses heats apartments in same building as vertical farm, hence helping in cope up with cost[49]. Use of renewable energy is also a helpful method to deal with cost crisis. 
Table 3: summary of modelled annual data with standard deviations[10]

\begin{tabular}{|l|l|l|l|l|l|l|}
\hline \multirow{2}{*}{$\begin{array}{l}\text { Production } \\
\text { Method }\end{array}$} & \multicolumn{2}{l}{ Yield(kg/m2/y) } & Water use $(\mathrm{L} / \mathrm{kg} / \mathrm{y})$ & \multicolumn{2}{l|}{ Energy Use $(\mathrm{kJ} / \mathrm{kg} / \mathrm{y})$} \\
\cline { 2 - 7 } & Value & S.D. & Value & S.D. & Value & S.D. \\
\hline Conventional & 3.9 & 0.21 & 250 & 25 & 1100 & 75 \\
\hline Hydroponics & 41 & 6.1 & 20 & 3.8 & 90,000 & 11,000 \\
\hline
\end{tabular}

\section{Renewable energy in Vertical Farming}

Energy use is one of the most important parameters in controlled environment which contributes to $20-30 \%$ of total cost[50]. VF demands energy which is to be used for lighting, maintaining temperature, water and nutrient supply and even for technical equipment's like conveyors, heat pump etc. As VF is aimed at increasing efficiency, hence more and more use of renewable energy is desirable. The most effectively used renewable energy is solar energy but wind energy can also be employed by installing turbines. Switch Glass can also be a substituent of coal as a energy source.

Solar energy may be the answer to this energy requirement[51]. Different methods of utilising solar energy include using solar walls, solar panel or even trump walls. The roofs of VF can be equipped with solar panels having high efficiency which converts about $30 \%$ of the total energy received into electrical energy. IF enough solar panels are installed, enough Watts of energy can be made available. The best example of which is the Metropolis Farms facility in Philadelphia[52]. They installed 2000 solar panels on the building roof that is capable of producing half Mega Watt of energy. The Vertical Farm to be implemented on the 4th floor of the facility will fully be run by the power generated by this solar panel.

Select solar cells should be used to absorb the non PAR waves from sunlight. These waves do not participate in photosynthesis and hence are useless. Solar cells can use them to produce photovoltaic energy.

\section{Intelligent Farming}

The concept of vertical farming is based on controlled environment agriculture (CEA) technology in which the environmental factors within the system are controlled. Intelligent Vertical farming is when these environmental factors are controlled automatically with minimal human interaction. The methods by which this can be done include: Environment Factor control using IOT[53][51], PLC[54], Deep neural networks [55], reinforcement learning [56]etc. to control irrigation system, hydroponic nutrient content, LED activation and de-activation, temperature control etc.

In order to monitor the necessary conditions of the plant effectively in an agriculture system, the integration of farming system and IOT is necessary. Such implementation may help save farmers resources and reduce the percentage of harmful chemicals in their production/plantation [57]. A basic process of IOT integrated system is:

Cultivation - Sensors - IOT service (data) centre - Data and prediction- Cultivation

This system can be easily controlled and manipulated according to the needs and requirement.[58][59] For example, to open the water tap by a phone when humidity sensor detects low water levels. This helps farmers react quickly to ensure crop safety no matter where they are. Hence implementation and interconnection of an IOT system with the hardware components of the agricultural system not only automates the entire system, thus increasing efficiency but also helps in resource reuse and recycle. Another advantage being automatic irrigation which helps save water and hence money.

The temperature and humidity sensor continuously detects the data and sends it to the IOT service centre. Here, the received data is checked with the predefined data and a control signal is given accordingly. The liquid level is controlled using solenoid valve whereas temperature is controlled by a fan and bulb arrangement. Acidic and alkaline solution to prepare hydroponic solution should be kept in different tanks. These tanks should then be placed on the sides of a main water supply tank. LED strips (blue and red) are attached to promote plant growth. On Implementing this system, the system can be controlled by the user (by an application or web browser) once internet connection is established. For example, when water level drops in the system, the humidity sensor detects it and stores it in the Arduino allocated memory platform from where via a Ethernet module data is sent to user mobile. If the value given by humidity sensor is below a definite value, it will indicate that the water content is low. Hence when the user presses the water button, the solenoid valve opens and when the humidity sensor value is equal to or more than the pre-defined value the valve closes automatically thus indicating sufficient water level. Similarly LED lights can also be controlled over the internet via this IOT implementation. Vertical farming systems using intelligence are given below

[14] presented a OWL based Vertical farm ontology model for better understanding of relationships between various domain factors. In the given model, IOT information is recompiled and made understandable for other systems. It provided a great way for development of intelligent and smart agricultural practices.

(Yap Shien Chin et al. 2017) In this project vertical crop monitoring system is designed to keep track of crops physical conditions. Varieties of sensors are used to identify physical conditions using BBB microcontroller and Thingspeak cloud. It also includes equipment position tracking for easy maintenance. Web based application displays the data gathered.

[37] It involves growing of lettuce (Rex, Nanda and Canasta) rotatory system and also cabbage in a cylindrical multitier system with hydroponics using RB( Red and BLUE) Led lightening. PAR (Photo synthetically Active 
Radiations) at $63 \mu \mathrm{mol} / \mathrm{m} 2$ level produced better development in Canasta but low fresh weight in 'Rex' and 'Nanda'. Cultivation of cabbage in vertical stack system within cylindrical unit produced $47 \%$ more plant density in comparison to rotation system.

[60] The basic idea behind this project is monitoring of soil moisture content and controlling of water content via web browser through mobile phone, laptop or other handheld devices. Main part of project is soil moisture sensor which detects moisture in vertical farm so as to have enough monitored and controlled water. Web browser is used to read status of soil moisture and release water tap when lower content is detected.

[61] In this project author develops a sensor array to monitor or measure various parameters effecting plant conditions in vertical farm. For storing data and sending it uses Thingspeak cloud and Intel Edison wireless module. SMS facility is also included based on Virtuino app.

[62] This system includes a network that control two different components and gather all data while transceiving. This system controls various factors for plant growth and uses mobile application to adapt and execute.

\begin{tabular}{|c|c|c|c|c|c|c|c|c|}
\hline $\begin{array}{l}\text { Scienti } \\
\text { st/ } \\
\text { Refere } \\
\text { nce } \\
\end{array}$ & $\begin{array}{c}\text { Sensors } \\
\text { used }\end{array}$ & $\begin{array}{c}\text { Plant/no. } \\
\text { of tiers }\end{array}$ & $\begin{array}{c}\text { Technique/ } \\
\text { environme } \\
\text { nt }\end{array}$ & $\begin{array}{l}\text { microcontr } \\
\text { oller }\end{array}$ & $\begin{array}{l}\text { Source of } \\
\text { light }\end{array}$ & $\begin{array}{c}\text { Data } \\
\text { storage }\end{array}$ & $\begin{array}{c}\text { Extr } \\
\text { a } \\
\text { featu } \\
\text { res }\end{array}$ & $\begin{array}{c}\text { User } \\
\text { interface }\end{array}$ \\
\hline $\begin{array}{c}\text { (Yap } \\
\text { Shien } \\
\text { Chin et } \\
\text { al. } \\
2017 \text { ) }\end{array}$ & $\begin{array}{c}\text { LDR } \\
\text { photo } \\
\text { resistor, } \\
\text { LM35 } \\
\text { temp } \\
\text { sensor, } \\
\text { soil } \\
\text { moisture } \\
\text { sensor }\end{array}$ & $-/ 3$ & Soil/indoor & BBB & $\begin{array}{l}\text { RGB } \\
\text { LED }\end{array}$ & $\begin{array}{l}\text { Thingsp } \\
\text { eak } \\
\text { cloud }\end{array}$ & $\begin{array}{c}\text { GPS } \\
\text { recei } \\
\text { ver in } \\
\text { wirel } \\
\text { ess } \\
\text { modu } \\
\text { le to } \\
\text { detect } \\
\text { locati } \\
\text { on of } \\
\text { senso } \\
\text { rs }\end{array}$ & $\begin{array}{c}\text { Self- } \\
\text { designed } \\
\text { app }\end{array}$ \\
\hline [60] & $\begin{array}{c}\text { Soil } \\
\text { moisture } \\
\text { / water } \\
\text { level } \\
\text { sensor }\end{array}$ & $\begin{array}{c}\text { Herb } \\
\text { Typhoniu } \\
\text { m } \\
\text { Flagellifor } \\
\text { me/4 }\end{array}$ & $\begin{array}{l}\text { Soil loamy/ } \\
\text { indoor }\end{array}$ & $\begin{array}{l}\text { Arduino } \\
\text { IDE }\end{array}$ & LED & & & \\
\hline [61] & $\begin{array}{l}\text { Sensor } \\
\text { array: } \\
\text { light } \\
\text { sensor, } \\
\text { soil } \\
\text { sensor, } \\
\text { humidity } \\
\text { sensor } \\
\text { temperat } \\
\text { ure } \\
\text { sensor }\end{array}$ & $-/ 5$ & Soil/indoor & - & LED & $\begin{array}{l}\text { Thingsp } \\
\text { eak } \\
\text { cloud }\end{array}$ & & $\begin{array}{l}\text { Virtuino } \\
\text { app / SMS } \\
\text { sending }\end{array}$ \\
\hline [62] & $\begin{array}{l}\text { Tempera } \\
\text { ture and } \\
\text { humidity } \\
\text { sensor }\end{array}$ & - & $\begin{array}{l}\text { Aeroponics } \\
\text { /indoor }\end{array}$ & $\begin{array}{l}\text { Linux based } \\
\text { Raspberry Pi }\end{array}$ & LED & $\begin{array}{l}\text { Networ } \\
\mathrm{k} \\
\text { assisted } \\
\text { storage }\end{array}$ & $\begin{array}{l}\text { Mast } \\
\text { er } \\
\text { and } \\
\text { Slave } \\
\text { cham } \\
\text { ber } \\
\end{array}$ & $\begin{array}{c}\text { Computer } \\
\text { program } / \mathrm{m} \\
\text { obile app }\end{array}$ \\
\hline [33] & - & $\begin{array}{l}\text { Onion/ } 30 \\
\text { tiers of } \\
\text { trough }\end{array}$ & $\begin{array}{c}\text { Hydroponic } \\
\text { S }\end{array}$ & - & sunlight & - & - & $\begin{array}{c}\text { A shape } \\
\text { rotatory } \\
\text { arrangeme } \\
\text { nt }\end{array}$ \\
\hline [37] & $\begin{array}{l}\text { LI-CON } \\
\text { light } \\
\text { meter } \\
\text { quantum } \\
\text { sensor }\end{array}$ & $\begin{array}{l}\text { Lettuce: } \\
\text { 'Rex', } \\
\text { 'Nanda' } \\
\text { and } \\
\text { 'Canasta'/ } \\
2 \text { tiers } \\
\end{array}$ & $\begin{array}{l}\text { Hydroponic } \\
\text { / outdoor }\end{array}$ & - & $\mathrm{RB}(3: 1)$ & - & - & $\begin{array}{l}\text { Rotatory } \\
\text { system }\end{array}$ \\
\hline
\end{tabular}




\section{PLC based smart VF}

The VF system is same in case of PLC as discussed in case of IOT implementation.

[54] It proposes a monitoring system to manage unexpected power failures in a vertical fish farm with the use of PLC and ICT as these failures are the main reason for mortality of fishes in farm. This system is simple and helps to take instant action when in crisis. It also uses RUDP in transmission layer to minimize signal losses which is a concern due to use of PLC technology. It also includes a mobile application which allows users to observe and manage farm activities like sea water control, accessing farm and location checks, withdrawal period, photo period and batteries of system.

[51]designed system using three layers of PVC pipes horizontally stacked to represent vertical layers. Pipes connected by a solenoid valves are placed and on top a water tank was placed. On both sides of the tank, separate containers were placed to keep the alkaline and acidic solutions. The side walls of the system were attached with LED strips( Blue and Red) to facilitate plant growth. On the top, an exhaust fan and bulb were placed to control the temperature. The system is controlled by a Delta DVP- SS2 PLC. The temperature sensor continuously monitors the internal temperature and if the temperature exceeds a predefined value, the exhaust fan is turned on and when the temperature becomes equal to the pre defined value, fan is switched off. In case the temperature falls, the bulb is used to heat up the system. The PH level is continuously detected by a PH sensor dipped in hydroponic solution. It checks that the nutrient mixture is neither too acidic nor too alkaline. A humidity sensor is also employed which continuously monitors and maintains the water level of the system. The water level in pipes was maintained by a magnetic float level sensor and when water reduces than a specified value, the water is filled in the pipe from the supply tank by the solenoid valve. More smart VF systems can be achieved by using Deep neural networks, fuzzy logic etc.

\section{Conclusion}

Vertical Farming is a prospect that must be explored if the rising world food demands are to be met. They can help boost food production numbers which will reduce food pressure from rural agricultural lands. Unoccupied, large areas in dense urban areas can be easily used to implement VF. In this way, the area will be utilised whereas earlier it was being wasted. Also at times like these where climate change is affecting our crops and vegetation in a negative way, VF can prove beneficial to protect us from the ill effects of climate change and thus maintaining food and nutrient quality. The fact that VF has the ability to combat problems faced by normal agricultural techniques like pest attack, use of fertilisers etc. makes it more valuable. More studies should be conducted so as to implement more and more plants and crops in vertical farming system. Further research should be done on increasing the efficiency of the system design and structure. Also integration of VF with recent technological advancements like learning and data analytics techniques could prove to be useful. Work should be done this technique available to every individual or house in urban areas so that they can grow their own food without pesticides and also use this for gardening purposes.

\section{References}

1. “1eef1bf425ed54410f14a69e74097aeaebd681c1@ grow.verticrop.com.”.

2. “2018-Revision-of-World-Urbanization-Prospects@Www.Un.Org." .

3. “24adc0d2d2b938a8d1a11ee1142181be5de21b41@ aerofarms.com.”.

4. “30a89aae7b898dc17a529b6d8280625c21a48c05@www.verticalfarming.com.”.

5. “84855d2fa11a77afe31ca80dc09e997d7c689200@www.environmentalleader.com.”.

6. “abe7b7afccac5e9163c4a1150a3f1bdff597ad5a@greenturf.asia.”.

7. "global-demand-for-food-is-rising-can-we-meet-it @ hbr.org." .

8. "home@www.freightfarms.com.".

9. "Index@ Aerofarms.Com.".

10. "index@ cropbox.co.".

11. "index@omegagarden.com.”.

12. “index@plantchicago.org.".

13. "index@www.brooklyngrangefarm.com.".

14. “index@www.greengirlproduce.com.”.

15. "index@www.growtainers.com.".

16. “index@www.skygreens.com.”.

17. “nuvege@agritecture.tumblr.com.”.

18. "two-thirds-of-global-population-will-live-in-cities-by-2050-un-says @www.cnbc.com.”.

19. "vertical-gardens-a-look-into-six-of-the-worlds-best-green-walls@ theurbandeveloper.com.”.

20. "World-Population-Prospects-2017@Www.Un.Org.".

21. Cohen, S. Malone, Z. Morris, M. Weissburg, and B. Bras, "Combined Fish and Lettuce Cultivation : An Aquaponics Life Cycle Assessment," Procedia CIRP, vol. 69, no. May, pp. 551-556, 2018.

22. Dahlberg, "Can vertical farms outgrow their cost ? An analysis of the competitive strength of vertical farms in Sweden Master's thesis in Management and Economics of Innovation," 2019.

23. G. Nair, A. Chacko, G. Mohan, and T. K. Francis, "Smart Vertical Farming Using Hydroponics," vol. X, no. X, pp. 14-17, 2015. 
24. Khanna and S. Kaur, "Evolution of Internet of Things (IoT) and its significant impact in the field of Precision Agriculture," Comput. Electron. Agric., vol. 157, no. January, pp. 218-231, 2019.

25. N. Harun, R. Ahmad, and N. Mohamed, "Plant growth optimization using variable intensity and Far Red LED treatment in indoor farming," 2015 Int. Conf. Smart Sensors Appl. ICSSA 2015, pp. 92-97, 2015.

26. N. Redacted, "Plant Growth as a Function of LED Lights," vol. 3, no. April 2009, 2011.

27. J. Birkby, "Vertical Farming," pp. 1-12, 2016.

28. N. S. Murthy, F. Karimi, R. H. Laxman, and V. S. J. Sunoj, "Response of strawberry cv. Festival grown under vertical soilless culture system," Indian J. Hortic., vol. 73, no. 2, pp. 300-303, 2016.

29. Yep and Y. Zheng, “Aquaponic trends and challenges e A review,” J. Clean. Prod., vol. 228, pp. 1586-1599, 2019.

30. Banerjee, "Up, Up and Away! The Economics of Vertical Farming,” vol. 2, no. 1, pp. 40-60, 2014.

31. K. Keat and C. Kannan, "Development of a Cylindrical Hydroponics System for Vertical Farming," vol. 5, pp. 93-100, 2015.

32. Peuchpanngarm, P. Srinitiworawong, W. Samerjai, and T. Sunetnanta, "DIY Sensor-Based Automatic Control Mobile I $\curvearrowright$ ' I,’ 2016.

33. Despommier, "The vertical farm : controlled environment agriculture carried out in tall buildings would create greater food safety and security for large urban populations," pp. 233-236, 2011.

34. Touliatos, I. C. Dodd, and M. Mcainsh, "Vertical farming increases lettuce yield per unit area compared to conventional horizontal hydroponics," Food Energy Secur., vol. 5, no. 3, pp. 184-191, 2016.

35. Molin and M. Martin, Assessing the energy and environmental performance of vertical hydroponic farming In cooperation with Grönska Stadsodling, no. C 299. 2018.

36. Bu and $\mathrm{X}$. Wang, "A smart agriculture IoT system based on deep reinforcement learning," Futur. Gener. Comput. Syst., vol. 99, pp. 500-507, 2019.

37. C. L. Belista, M. P. C. Go, L. L. Lucenara, C. J. G. Policarpio, X. J. M. Tan, and R. G. Baldovino, “A Smart Aeroponic Tailored for IoT Vertical Agriculture using Network Connected Modular Environmental Chambers," pp. 1-4, 2019.

38. L. Barbosa, F. Daiane, A. Gadelha, and N. Kublik, "Comparison of Land, Water, and Energy Requirements of Lettuce Grown Using Hydroponic vs . Conventional Agricultural Methods,” pp. 6879-6891, 2015.

39. Lavanya, C. Rani, and P. Ganeshkumar, "An automated low cost IoT based Fertilizer Intimation System for smart agriculture,” Sustain. Comput. Informatics Syst., no. 2018, pp. 1-12, 2019.

40. A. Kratsch, W. R. Graves, and R. J. Gladon, "Aeroponic system for control of root-zone atmosphere," vol. 55, no. October 2004, pp. 70-76, 2006.

41. Mok, V. G. Williamson, J. R. Grove, K. Burry, S. F. Barker, and A. J. Hamilton, "Strawberry fields forever ? Urban agriculture in developed countries : a review," pp. 21-43, 2014.

42. E. Son, H. J. Kim, and T. I. Ahn, Chapter 20 - Hydroponic systems. Elsevier Inc., 2020.

43. H. Huh, "PLC-based design of monitoring system for ICT-integrated vertical fish farm," Human-centric Comput. Inf. Sci., vol. 7, no. 1, 2017.

44. Al-Kodmany, "The vertical farm: A review of developments and implications for the vertical city," Buildings, vol. 8, no. 2, 2018.

45. Loman Jan Luciano, "Vertical Farming Can it chnage the global food production landscape?," TIAA-CREF Glob. Agric., no. 1601, 2018.

46. Gentry, "Local heat, local food: Integrating vertical hydroponic farming with district heating in Sweden," Energy, vol. 174, pp. 191-197, 2019.

47. I. H. Bin Ismail and N. M. Thamrin, "IoT implementation for indoor vertical farming watering system," 2017 Int. Conf. Electr. Electron. Syst. Eng. ICEESE 2017, vol. 2018-Janua, pp. 89-94, 2018.

48. K. hirofumi Ibaysahi, Yukimasa Kaneda, Jungo Imahara, Naoki Oishi, "A Reliable Wireless Control System for Tomato Hydroponics."

49. M. Mehra, S. Saxena, S. Sankaranarayanan, R. J. Tom, and M. Veeramanikandan, "IoT based hydroponics system using Deep Neural Networks," Comput. Electron. Agric., vol. 155, no. August, pp. 473-486, 2018.

50. Ahmad, "Energy for Metropolis," Univ. Miami Law Rev., vol. 73, no. 1, p. 258, 2018.

51. N. Ecija, M. P. Pascual, G. A. Lorenzo, and A. G. Gabriel, "Vertical Farming Using Hydroponic System : Toward a Sustainable Onion Production in," pp. 25-41, 2018.

52. N. Mittal, U. Singh, and B. S. Sohi, “A novel energy efficient stable clustering approach for wireless sensor networks," Wirel. Pers. Commun., vol. 95, no. 3, pp. 2947-2971, 2017.

53. Hamshere, Y. Sheng, B. Moir, and F. Syed, What India wants: Analysis of India's food demand to 2050, no. 14. 2014

54. Pinstrup-Andersen, "Is it time to take vertical indoor farming seriously?," Glob. Food Sec., vol. 17, no. August, pp. 233-235, 2018.

55. Brumfield, "Dealing with rising energy costs," Greenh. Prod. News, vol. 17, no. March, pp. 24-31, 2007. 
56. Bhowmick, B. Biswas, M. Biswas, A. Dey, S. Roy, and S. K. Sarkar, Advances in Communication, Devices and Networking, vol. 537. Springer Singapore, 2019.

57. Millam and S. K. Sharma, Soil-Free Techniques. Elsevier B.V., 2007.

58. S. S. S. Yusof, N. M. Thamrin, M. K. Nordin, A. S. M. Yusoff, and N. J. Sidik, "Effect of artificial lighting on typhonium flagelliforme for indoor vertical farming," Proc. - 2016 IEEE Int. Conf. Autom. Control Intell. Syst. I2CACIS 2016, no. October, pp. 7-10, 2017.

59. S. Sivamani, N. Bae, and Y. Cho, "A smart service model based on ubiquitous sensor networks using vertical farm ontology,” Int. J. Distrib. Sens. Networks, vol. 2013, 2013.

60. Y. Kyaw and A. K. Ng, "ScienceDirect ScienceDirect ScienceDirect The 15th Aquaponics International Symposium System Urban Thu Ya Kyaw of Assessing the feasibility using Keong the heat function for a long-term district demand forecast," Energy Procedia, vol. 143, pp. 342-347, 2017.

61. X. P. Song, H. T. W. Tan, and P. Y. Tan, "Assessment of light adequacy for vertical farming in a tropical city,” Urban For. Urban Green., vol. 29, no. July 2017, pp. 49-57, 2018.

62. Y. Park and E. S. Runkle, "Spectral effects of light-emitting diodes on plant growth, visual color quality, and photosynthetic photon efficacy: White versus blue plus red radiation," PLoS One, vol. 13, no. 8, pp. 1-14, 2018. 